\title{
A macro-environment approach to civil aviation strategic planning
}

\author{
Nadine Itani, John F. O’Connell, Keith Mason \\ Department of Air Transport, Cranfield University, Bedfordshire MK43 0AL, United Kingdom \\ Tel.: +44 1234750111 Fax: +44 1234752940 \\ Email addresses: n.itani@cranfield.ac.uk; frankie.oconnell@cranfield.ac.uk; k.mason@cranfield.ac.uk
}

\begin{abstract}
$\underline{\text { Abstract }}$
Air transport is considered a cyclical industry sensitive to the macro-environment in which it operates. As aviation policy makers and regulators strategically plan for their future, they need to consider the systematic and synergistic effects of common factors which comprise the operating environment of the industry's organisations. Thus, during the process of aviation systems planning, governments should perceive the generic conditions which exist in the economy as a whole as equally important to air transport exclusive conditions. This paper highlights the significant impact of the national macro-environment factors on a country's air transport sector and it suggests including these elements within the context of civil aviation strategic planning. Country level data is collected on seventeen input variables versus four output variables on a sample of 52 countries. Structural Equation Modelling (SEM) is used to identify the descriptors with significant impact on air transport output, namely: passenger traffic, aviation total contribution to GDP, aviation total contribution to employment and air connectivity levels. The results call upon aviation regulators to assess the national macro-environment forces during the situational analysis within the strategic planning process. The identified operating environment conditions act as a framework for providing clear policy orientations and for facilitating the identification of areas where policy intervention could improve air transport sector's performance. A well-defined aviation strategy allows aviation policy makers to identify and address nationwide strategic issues and provides aviation industry's stakeholders with guidelines to help maintain and enhance their competitive position in both domestic and global markets.
\end{abstract}

KEYWORDS: macro-environment, civil aviation, strategic planning, SEM. 


\section{INTRODUCTION}

There are numerous definitions describing what strategy is. Like many other concepts in the field of management, there is no agreed, all-embracing definition of strategy (Burns, 2000). Even one of the pioneers of business strategy, Ansoff (1965), warned that strategy is an elusive and somewhat abstract concept. However, within the management and administrative context, strategic planning is a contemporary concept, identifiable within both the corporate and public arenas (Young, 2003) and defined as a formalized procedure to produce an articulated result in the form of an integrated system of decisions (Mintzberg, 2000). The literature points that government agencies do in fact benefit from the strategic planning process mainly because the development of multi-year policy plans links present situations or circumstances to a more meaningful vision of the future (Koteen, 1989; Nutt and Backoff, 1992; Young, 2001).

It is generally agreed, in both theory and practice, that the common steps involved in a strategic planning process are: (1) development of mission and vision; (2) environmental scan which includes and internal scan of the strengths and weaknesses and an external scan of the opportunities and threats; to reach (3) strategy formulation (Fig. 1). Besides, every strategic plan incorporates and "environmental scan" approach to the entity under study. The environmental school of thought ${ }^{1}$ places a significant weight on the macro-environment forces outside the organization. According to this school, the environment plays a central role in the strategy formation to the extent that the organization becomes subordinate to the environment (Mintzberg et al., 1998).

Nowadays, with such dramatic shifts in the normal operating environment, there is an increased need for strategic planning for tackling uncertainty and identifying key issues which will determine the future behaviour of the entity under study. However, in an ever-changing industry like the aviation industry, the outside forces such as: emerging markets, economic fluctuations, technological advancements, regulatory trends, political and security instability and other factors often form the basis for this uncertainty. As for civil aviation strategic planning, it is invariably

\footnotetext{
${ }^{1}$ More information about different schools of thought in strategy formation is available in Mintzberg et al. (1998).
} 
the role of the government to design the future of its aviation sector. In this case, a strategic planning process enables, for instance, the civil aviation policy makers and regulators:

- to identify the key factors which influence the performance of the sector;

- to ascertain the challenges and opportunities that present themselves;

- to understand clearly the current state of the national air transport sector;

- to determine what desirable future outcomes - such as boosting the social and economic contribution; and

- to draft the required policies to attain these outcomes - by following a more liberal air transport policy and encouraging private sector participation in the investment in, or procurement of, the aviation infrastructure.

Figure 1: Strategic planning model

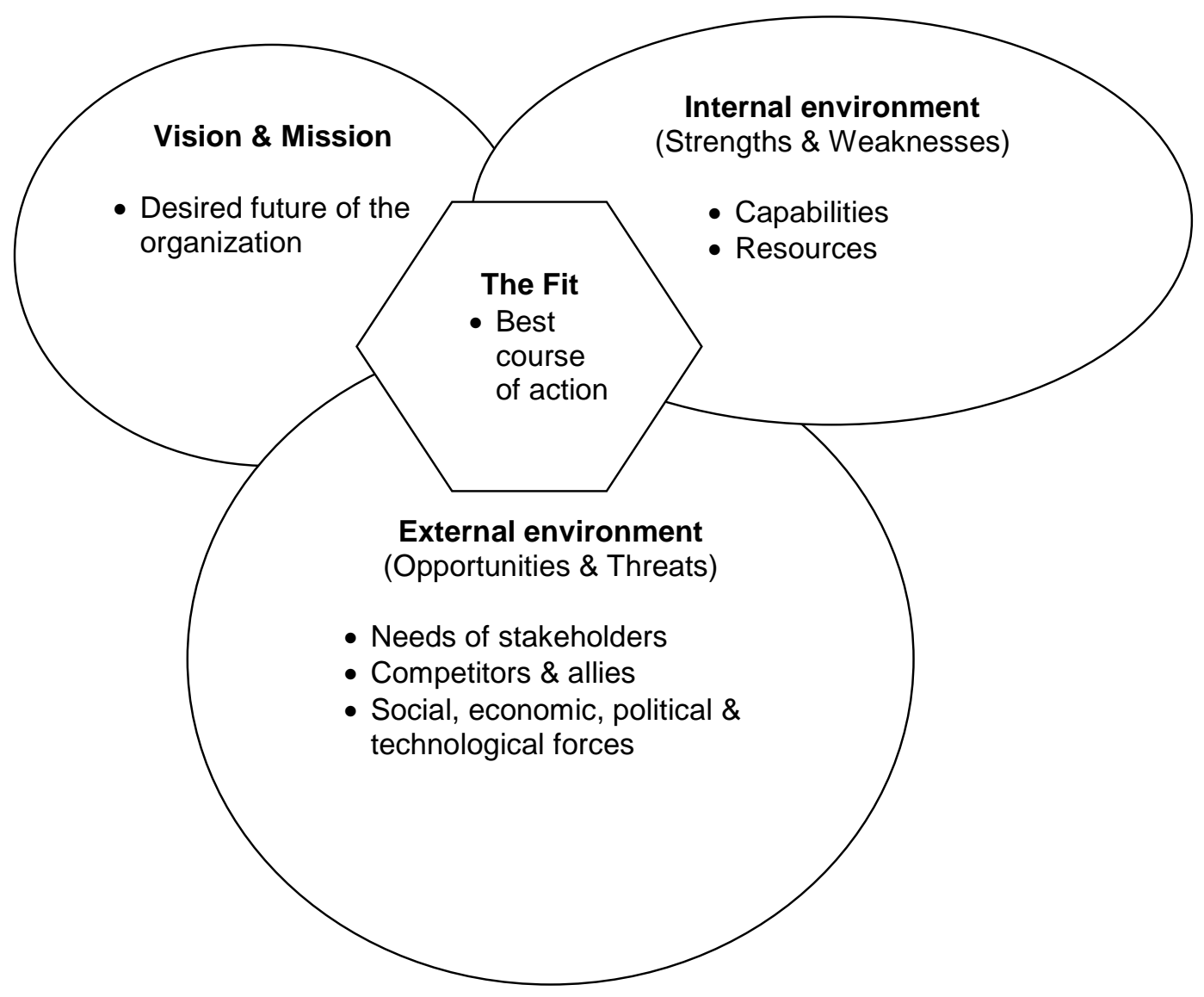

Source: Barry (1997) 
Applying a strategic planning framework from the industry regulators' perspective is largely consistent with, and comprises, the traditional strategic management process which includes environmental scanning, strategy formulation, strategy implementation, evaluation and control (Ricks and Woods, 1996; Thompson et al., 2004; Porter, 2004). However, the application of these management tools varies substantially because fundamental differences exist between the situation of a firm and that of an industry (Lyford et al., 2002).

This paper focuses on civil aviation strategic planning and examines the first step within the traditional strategic planning process - the environmental scan. It answers the following question: What are the national macro-environment factors with significant impact on air transport output? In Section 2, the paper looks into the factors of national competitiveness and selected socio-economic indicators, as building blocks of the aviation sector operating environment, then in Section 3 assess the significant impact of these factors on air transport industry performance by analysing a sample of 52 countries. Structural Equation Modelling (SEM) is employed to examine the correlation and dependence relationships among multiple variables. The aim of this analysis is to identify macro-environment variables which are significantly correlated with the national air transport sector output. The results provide evidence for the existence of this correlation that has implications for air transport policy orientation. The conclusion given in Section 4 calls for more coordination in aviation systems planning on a national level so that air transport policy is then placed within other national policies (e.g. trade, tourism and social policies) oriented for national growth and competitiveness.

\section{INFLUENCES OF NATIONAL MACRO-ENVIRONMENT VARIABLES ON AIR TRANSPORT SECTOR}

The macro-environment consists of broad conditions that exist in the economy as a whole, rather than in a particular sector. The number of possible strategic variables in the general environment, is enormous. Various authors like Fifield and Gilligan (2000); Henry (2010), have listed those variables in different ways, the most notable being the PEST framework of macro-environment which is an acronym for political/legal, economic, socio-cultural and technological variables. Generally, strategic planners consider these variables as part of the environmental scanning to 
better understand the threats and opportunities created by those factors and how strategic plans need to be adjusted so that firms or sectors can obtain and retain competitive advantage. The macro environment in which a firm or sector operates will influence its performance, and the amount of the influence will depend on how much of the sector's businesses are dependent on the health of the overall economy.

Cyclical industries, such as the air transport industry, are heavily influenced by the macroenvironment. Any change in the conditions of the fundamentals which drive or suppress growth will result in alternations to the air transport industry trends. This will also affect aviation-related enterprises which are susceptible to the PEST factors which exist in a given country.

To identify the factors which define the macro-environment on a country level, we looked at the different approaches used in measuring national competitiveness ${ }^{2}$. National competitiveness is defined as the ability of a country to use its natural, human and financial resources to achieve productivity and efficiency. The emergence of national competitiveness as an importsant policy goal has encourages the development of indicators by which policy-makers and practitioners can measure, analyse, and compare relative competitive performance. The growth of competitiveness indices reflects the growing emphasis placed on benchmarking - and the one receiving the greatest media attention - is the approach which ranks several nationsl in terms of national competitiveness in the form of a league table (Lall, 2001, WEF, 2012). This is done by building a system of indicators which are merged into a single, composite score and/or rank.

The first competitiveness index was produced in 1979 by the World Economic Forum (WEF) together with the Institute for Management Development (IMD). The index covered, at the time, 16 European countries only and was made up of four competitiveness factors, whereas the index published in the latest report in 2013 covers 148 countries and is based on 12 different pillars (WEF, 2013). Nowadays, the number of competitiveness reports has increased. However, the most common ones are the following: Global Competitiveness Report (GCR) of the WEF, the

\footnotetext{
${ }^{2}$ The term national competitiveness is frequently conceptualised in terms of the economy's overall performance in macroeconomic terms. In short, it is assumed that a higher degree of competitiveness leads to a higher productivity, and therefore to a higher standard of living (McFetridge, 1995). Porter (1998) asserts that national competitiveness is equivalent to productivity. This reflects the close links which Porterbelieves exist between the microeconomic productivity of an industry and the macroeconomic performance of the national economy.
} 
World Competitiveness Yearbook (WCY) of the IMD, the National Competitiveness Report (NCR) of the Institute of Industrial Policy Studies (IPS) and the International Location Ranking of the Bertelsmann Foundation.

In this paper we considered the factors of national competitiveness as identified in the WEF, in addition to other socio-political factors, as the macro-environment within which industries and sectors in given nations operate. The reason for selecting the WEF-GCR variables specifically, rather than variables available in other reports, is that the WEF is the first independent non-profit organisation to publish reports on competitiveness since 1979, with the GCR having been published since 1996. Rankings of national competitiveness received much attention because that are also seen as proxies for future wealth and economic growth. This is important for policy makers and it makes the Global Competitiveness Index (GCI) compatible with the paper's objectives of identifying macro-environment factors with policy implications that impact on the air transport industry output. The methodology used by the WEF in measuring competitiveness has been developed almost continuously with the GCI first introduced in 2004. This index is based on 12 different pillars which build up the three sub-indices ${ }^{3}$. Depending on the stage of development according to Porter (1998) approach these sub-indices are weighted differently when aggregated. The weights of the 12 pillars are fixed according to the results of a regression. Of the 113 variables included in the 2009 report, 73 are survey-based. This makes the WEF ranking on national competitiveness the one with the greatest share of survey data, based on more than 11,000 respondents.

Studies on competitiveness indices are rate and little is known about the grounding in theory and methodology with notable exceptions such as Lall (2001) who focuses on the WEF report, and Hanke and Walters (1997), Rouvinen (2001) and Vartia and Nikinmaa (2004) who focus on IMD and WEF reports. However, other reserachers have provided a critical evaluation of the role and validity of indices used to measure national competitiveness. Oral and Chabchoub (1996) and Berger and Bristow (2009) explained that benchmarking indices are confronted with a number of key challenges, mainly the choice of variables and how to aggregate them into a composite indicators for ranking purposes. However, the use of ranking and composite indicators in policy making has been used widely by policy markets and has proved their advantages despite the

\footnotetext{
${ }^{3}$ The three sub-indices as identified by WEF in the GCR are: basic requirements, efficiency enhancers and innovation factors.
} 
different critiques of the conceptual framework guiding this process (Saisana and Tarantola, 2002).

The 12 different pillars on which the GCI is based are factors of different dimensions (economic, technological, legal and social) and determine the level of productivity of a given country. These 12 pillars are: (1) institutions (2) infrastructure (3) economic environment (4) health and primary education (5) higher education and training (6) goods market efficiency (7) labor market efficiency (8) financial market development (9) technological readiness (10) market size (11) business sophistication and (12) innovation. Five factors have been added to the before mentioned 12 which are: (13) economic stage of development (14) travel and tourism competitiveness (15) population count (16) country size and (17) level of political and security stability. Hypothetically, these additional factors are looked upon as associated to the output of air transport sector, as will be illustrated in the next section through the presented literature review which provides sufficient examples on this relationship. In this study, we will identify numerically the ones that are significant within their operating environment where this significance has policy implications and can be used to guide future developments.

While all of the pillars described above will matter to a certain extent for all nations, it is clear that they will affect them differently because they are country-specific. The combined effect of these factors produces varied operating environments in different countries. In other words and in order to succeed, civil aviation strategic planners should be able to identify the macro-level determinants of competitiveness of the country's air transport sector. While formulating competitive strategies, air transport policy makers and regulators have to scan external macroenvironment factors surrounding the air transport sector. This will assist in developing an understanding of the total, albeit complex economic, political, social and technological operating conditions.

The review of literature provides examples on the impact of macro-environment factors which stimulate air transport performance and hence enable this sector to contribute positively to the social and economic welfare of a nation. However, no previous studies have examined the aggregate impact of all these factors together. This paper uses an exploratory research method 
that combines literature review and country level data analyses to identify national macroenvironment variables which significantly impact on a country's air transport industry output.

\subsection{Political/legal factors:}

A country's political and legal environment is analysed through information describing the state of the public institutions, the structure of the legal framework, governmental policies and regulations and the level of political and security stability. These mentioned factors are critical and have direct influence aviation activities. No economic transformation can take place without institutions that allow markets to function properly. The institutional environment forms the framework within which individuals, firms, and governments interact to generate income and wealth in the economy. This framework has a strong bearing on competitiveness and growth. It plays a central role in the ways in which societies distribute the benefits and bear the costs of development strategies and policies, and it influences investment decisions and the organization of production (WEF, 2012).

The importance of institutions is not restricted to the legal framework. Government attitudes toward markets and freedoms and the efficiency of its operations are also very important; excessive bureaucracy, overregulation, corruption, dishonesty in dealing with public contracts, lack of transparency and trustworthiness, or the political dependence of the judicial system impose significant economic costs to businesses and slow down the process of economic development (De Soto 2000).

The country's institutional framework plays an important role in enabling the flows of foreign capital and the development of new industries. The economies of UAE, China and South Africa were effectively isolated from the global economy until the institutional and political reforms were implemented over the last several decades. Similarly, air transportation demand increased in China after the government decided to pursue two-stage economic reforms and opening up policies in the early 1980s and 1990s. Domestic demand for air travel in China multiplied 20 times, growing at an average of $18 \%$ a year complared with an average annual growth of $8.9 \%$ for all modes of transport (Boeing, 2010). 
Another example is the government of Dubai pursued changes in the institutional framework, invested into the supporting physical infrastructure and the development of the aviation infrastructure. The government of Dubai supported the expansion strategy of the national carrier in order to promote the growth of business and leisure passenger flows which enabled the flows of investment, high-skill labour, services, knowledge and tourism (Fig. 2). Infrastructure and aircraft comprise only half the equation, however. The other necessary element for a rapidly expanding aviation sector is a capable and comprehensive institutional and regulatory model to oversee it (Majdalani et al., 2010)

\section{Figure 2: Dubai airport - total passengers versus aviation development plans (1997-2011)}

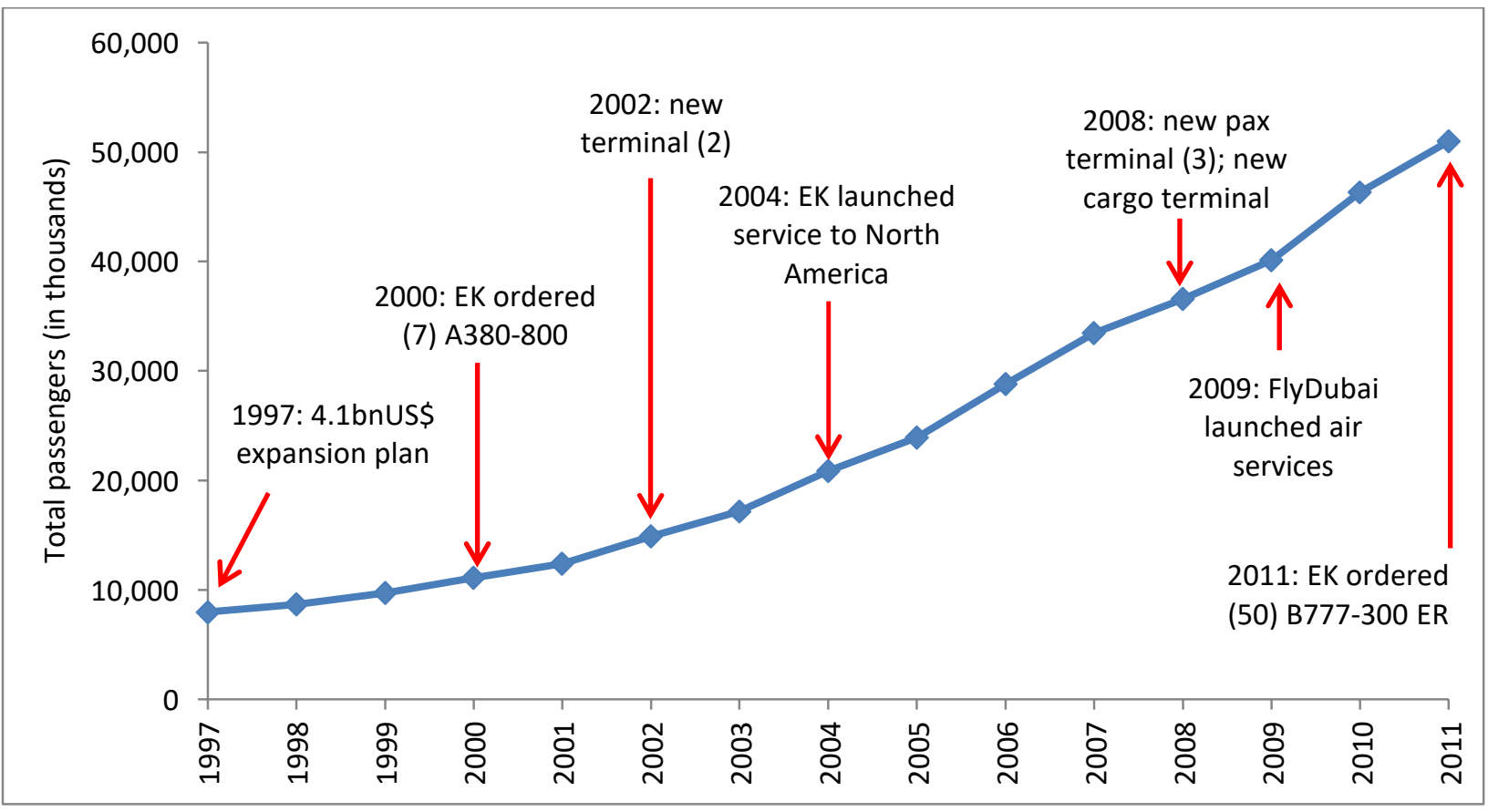

Source: (ICAO Data 2012) (Flight Global (2013)

If air transport is about facilitating and supporting the movement of people and cargo in order to achieve maximum economic benefits, political and security unrest certainly become the real challenges and threats to these goals. Political instabilities include unstable political system where government authorities are continuously changing, political conflicts between internal political parties, and the lack of strong leadership that creates financial and socio-political problems. Security risks include political unrest due to civil wars and conflicts, politically or religiously related assassinations, terrorism and other violent actions. 
Inbound and outbound travel demand is also influenced by the external political and economic sanctions which restrict air transportation access to the economy. Past and recent histories are rich with examples on the negative impact of political sanctions and security instability on air transport growth. Libya, Syria and Sudan's air transportation system development was surpressed due to economic and political sanctions. The nations' flag carriers could not modernize their fleet because of the US embargo on the export of high-technology equipment placed in the early 1980s (Vandyke, 1991). The embargo prevented the airlines from buying new aircraft, obtaining spares and other high-tech equipment (Endres, 2008; Chochrane, 2009; Laessing and Abdelaziz, 2011).

Similarly, South Africa was isolated from the global economy during the decades of the apartheid era which ended in the early 1990s. Until then, geopolitical restrictions associated with the apartheid played a substantial role in international operations of airlines in South Africa (Pirie, 1992). These restrictions included revocation of landing and overflying rights of South African Airways, the nation's state-owned national airline, by other African governments in the 1960s.

Geopolitical crises including wars affect the air transport sector. Perhaps the most extreme example being the September 11th terrorist attack in 2001 in the US, which of course had a greater impact on the aviation industry than on the rest of the economy (Alderighi and Cento, 2004). The Middle East provides plenty of examples on the impact of conflicts on air transport market. A recent example is the uprising of the Arab Spring in Egypt. The 25 January 2011 revolution had impacted on all facets of economic life in Egypt. Aviation, which contributes 8\% of Egypt GDP and supports approximately 1.3 million jobs has been severely affected (Oxford Economics, 2010). During the first quarter of 2011, the year-on-year drop of international arrivals was 46\%; an estimated loss of 2 billion US\$ (The Economist, 13 August 2011). Transportation remains the largest revenue generator within tourism in Egypt. Airlines still dominate transportation, especially as they are the main mode of transport for international travel $^{5}$. Airlines operating to Egypt suffered in 2011, with current revenue falling by $16 \%$

\footnotetext{
${ }^{5} 91 \%$ of international visitors arrive to Egypt by Air (Oxford Economics, 2010)
} 
compared to $10 \%$ drop for other modes of transport and decline by $14 \%$ in the number of passengers carried (Fig. 3).

Figure 3: Airlines operating to Egypt - sales, capacity and passengers carried (2006 - 2011)

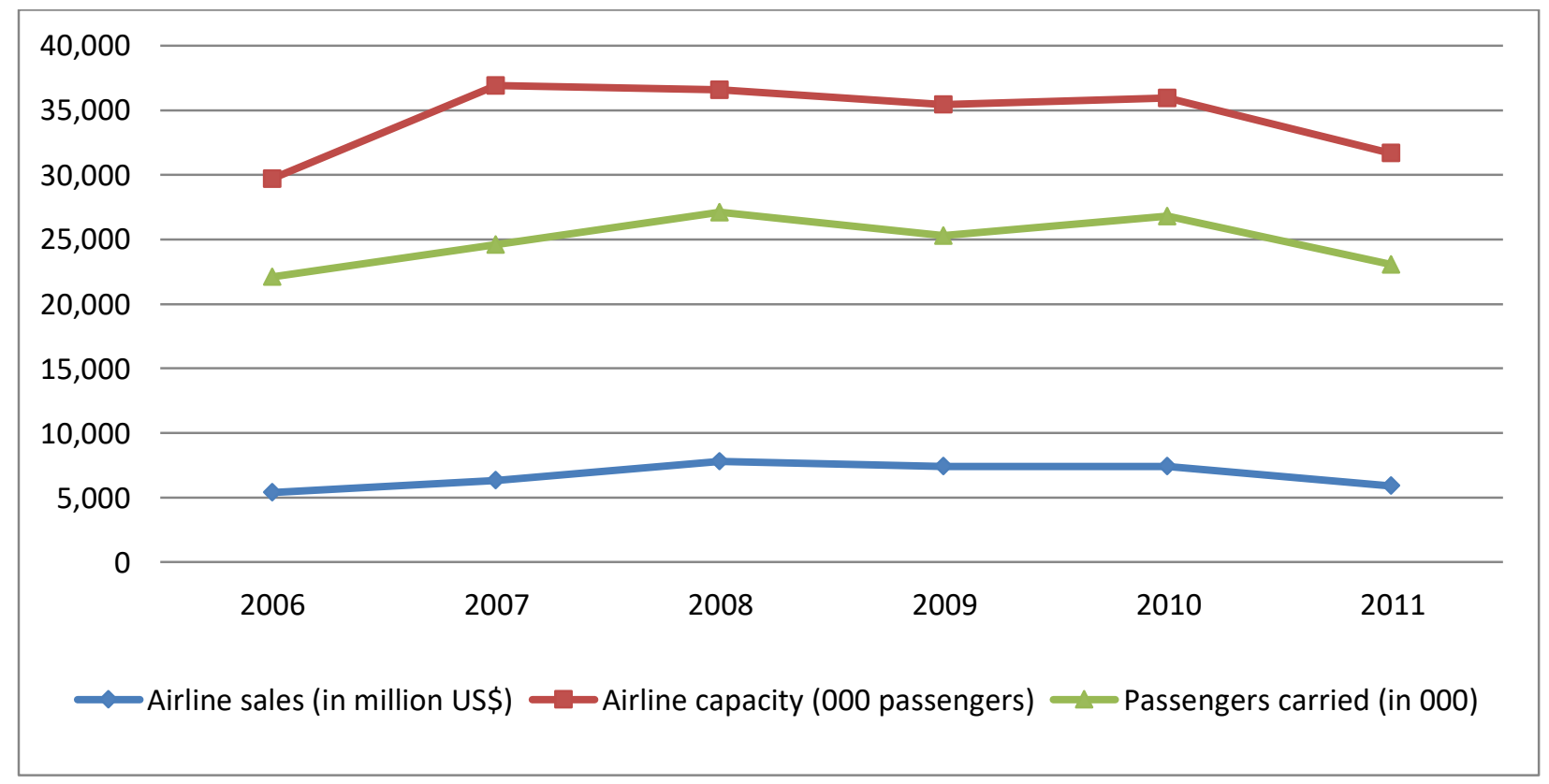

Source: (Euromonitor, 2012)

Egypt Air the national carrier which accounts for $45 \%$ of all capacity to and from Egypt saw its income drop by an estimated $80 \%$ during the first three months of 2011 compared to the same period in 2010. The airline incurred US\$80 million in losses in February 2011 and another US\$60 million in March. Additionally, the revolution halted the execution of aviation related investment projects. The ten year 2.4 billion US\$ program for modernizing and expanding the country's airports, was delayed in light of the revolution and the related turbulent state of tourism in the country, which tells us how attractive the field is.

\subsection{Economic factors:}

Air transportation services and economic development interact extensively. As a result, the availability of air transportation services effectively increases the scope and cycle time of 
economic activity. The region's economic activity in turn generates the need for passenger travel and freight and drives the demand for air transportation services. Over the years and as a result of the increase in air transportation usage, the number of studies describing the relationship between air transportation and economic activity has been increasing as well.

The International Civil Aviation Organization (ICAO) indicates that a high correlation exists between the growth patterns of air traffic and economic trends in that the demand for air transport is primarily driven by economic development (ICAO, Sept 2007). Therefore passenger traffic increased with the support of the strong performance of the world economy, while the economic downturn and other events have a negative impact on traffic (Fig. 4). 
Figure 4: Air Passengers and GDP by world regions (2000-2010)

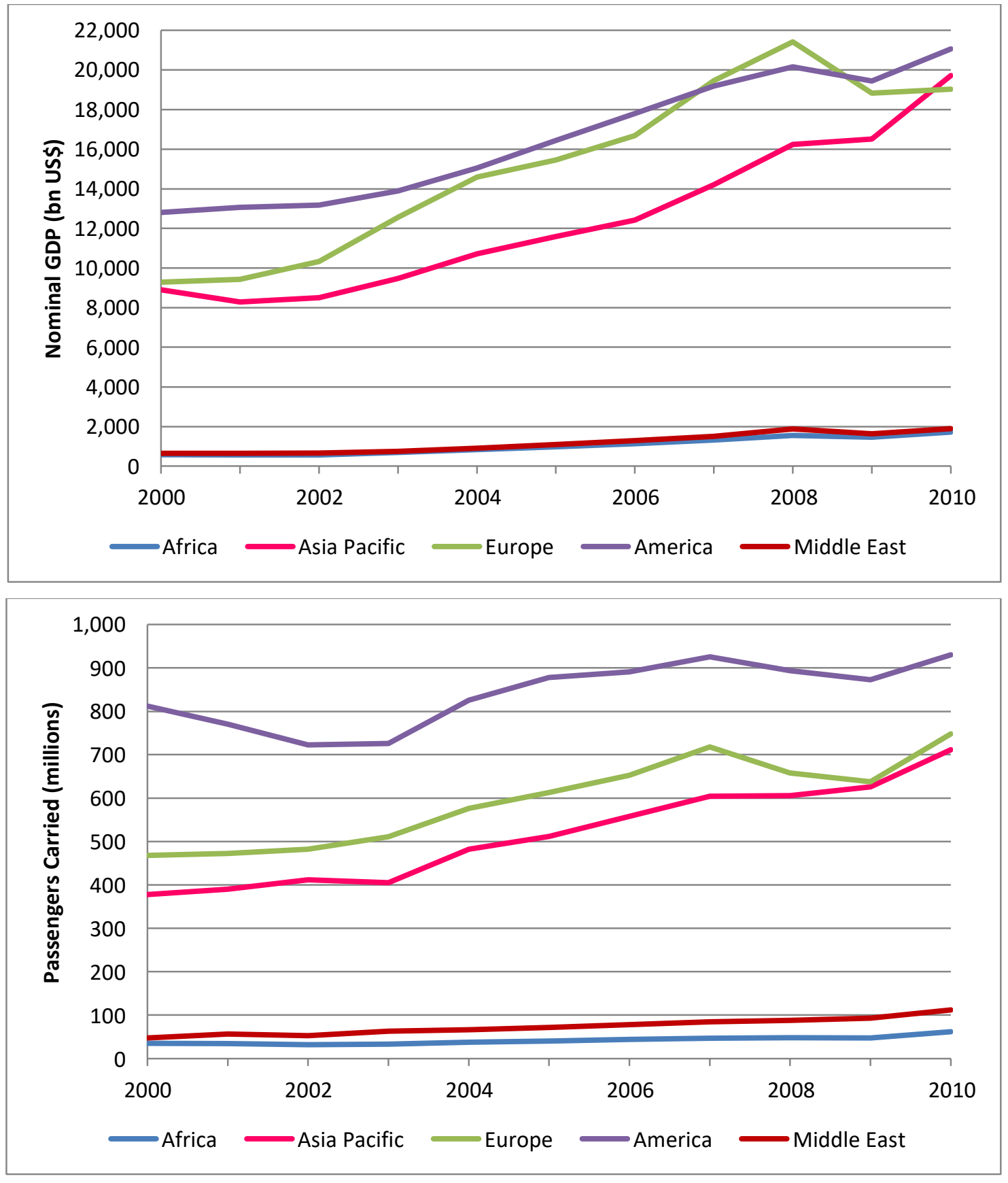

Source: (ICAODATA, 2010, IMF, 2012) 
Air transport traffic and the industry's revenues are very cyclical, which means that they are closely related to the economic situation (Hätty and Hollmeier, 2003; Button, 2009; Franke and John, 2011). Literature discussing the impact of the latest economic crisis is rich with examples which conclude that during the recent crisis, the higher the economic growth (or the lower the economic decrease), the more dynamic the air services at the national level are. Also, at the regional scale, Asian, South American, and Middle Eastern economic growth result in the development of air services, while the reverse is true in Europe, North America, or Japan (Dobruszkes and Van Hamme, 2011).

Also, other studies (Cooper and Smith, 2005; InterVISTAS-ga ${ }^{2}, 2006$; Ishutkina and Hansman 2009; ATAG, 2012) have analyzed the interaction between air transportation and economic activity. Their analysis confirmed that air transportation and economy are interdependent although the relationship between air transportation usage and economic activity is nonhomogeneous and complex. ${ }^{6}$

Additionally, there exist other factors that impact a set of attributes characterising a given economy and effecting air transport sector output. Among these factors we mention the country's infrastructure and its competitiveness in travel and tourism. Extensive and efficient infrastructure is an essential driver of competitiveness. It is critical for determining the position of economic activity and it reduces the distance between regions, with the result of truly integrating the national market and connecting it to markets in other countries and regions. A study conducted by the Inter-American Development Bank in 2004 concluded that the greater the investment in airport infrastructure, the lower the costs of air transport. The study adds that improvements in airport infrastructure-such as: airport expansion projects, new terminal buildings and runways,

\footnotetext{
${ }^{6}$ Depending on the combination of unique economic and air transportation attributes, different mechanisms dominate the relationship between air transportation and economic activity thus making this relationship complex. Such attributes include but are not limited to: the nature of air transportation flow (international vs. domestic traffic), the dominant purpose of passengers' visits, the level of economic dependency on tourism and the country's geographical location and proximity to resources.
} 
from 25 to $75 \%$ reduces air transport costs by $15 \%,{ }^{7}$ thus leading to significant growth in demand for air transport (IADB, 2004).

On the other hand, air transport infrastructure is pivotal for tourism development as slightly over half $(52 \%)$ of all tourist travellers arrived at their destination by air in 2012 (Fig. 5). However, many tourism-dependent, developing countries consider the enabling impact of tourism to be an integral part of their aviation sector development framework. As a result, they incentivize investment into air transportation and its supporting tourism infrastructure to increase the relative attractiveness of their economies to leisure travellers. Thus, a country with a competitive travel and tourism sector is prone to attract more visitors. And since the trend has been for air transport to grow at a faster pace than surface transport, so the share of air transport as a preferred mode of tourist transport is gradually increasing (UNWTO, 2013)

\section{Figure 5: Inbound tourism by mode of transport - World (2012)}

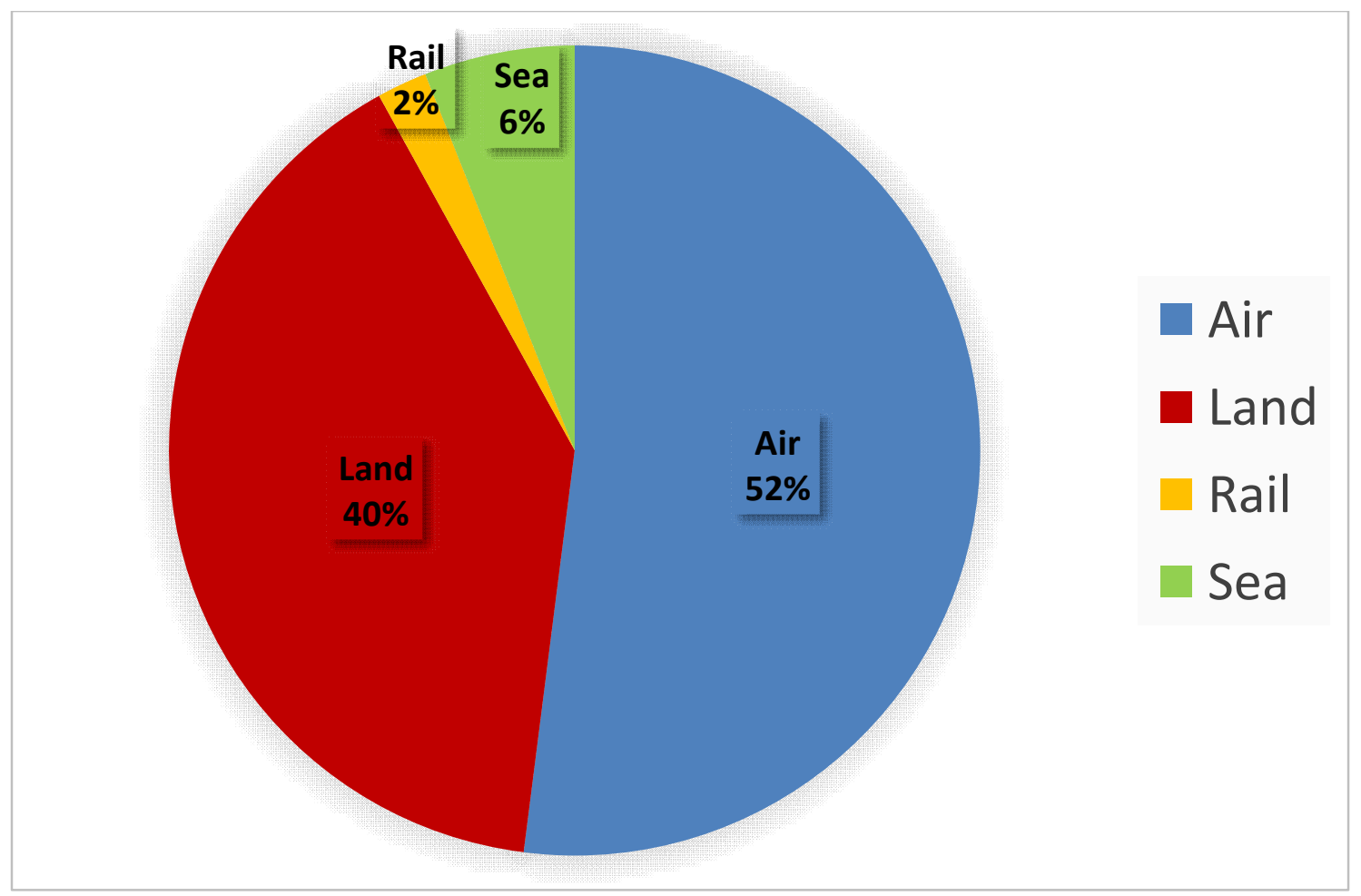

Source: (UNWTO, 2013)

\footnotetext{
${ }^{7}$ The IADB study quantifies the effects of infrastructure development on air transport costs through an empirical framework which uses a standard reduced from approach. More information on the study is available on: http://www.iadb.org/en/publications/publication-detail,7101.html?id=6611.
} 


\subsection{Socio-geographic factors:}

The socio-demographic factor is one among other factors of the macro-economic environment influencing the air travel supply and demand interactions. Socio-demographics include among others: population count, volume of national expatriate communities, and country size.

Theoretically, population size has always been considered a main drive for domestic air travel. This is evident through population usage in different models as an explanatory variable to domestic air travel demand, besides others (Poore, 1993; Schafer and Victor, 2000; Intervistas-ga2, 2006). As for international travel, the gravity model-an empirical model describing the level of interaction between two geographic locations-assumes that the level of interaction between a pair of locations is proportional to their respective populations and inversely proportional to the distance between them (Rodrigue et al., 2013).

\section{Figure 7: Air trips per capita versus GDP per capita (2009)}

7.0 Air trips per capita per year

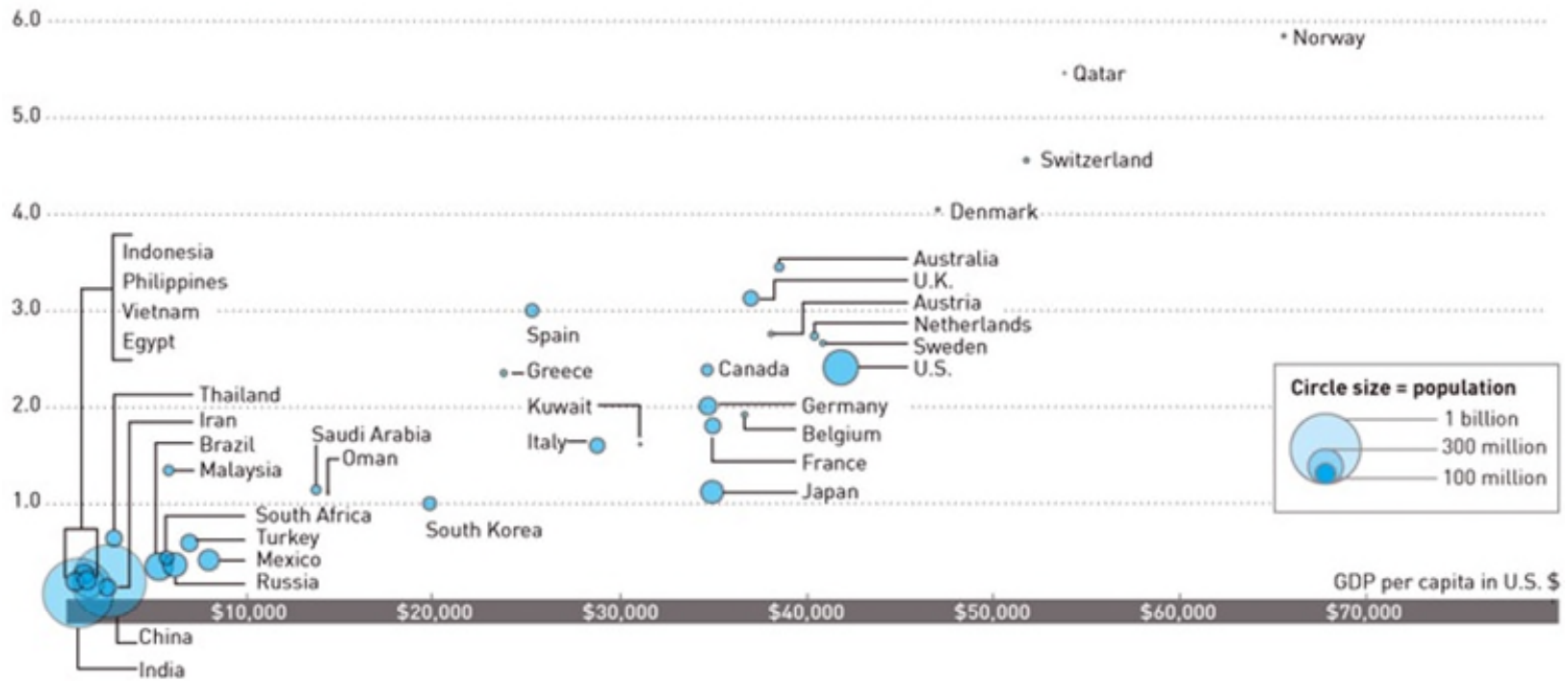

Source: (OAG Aviation, 2009; World Bank, 2009) 
However, high population volumes are not necessarily associated with a growing passenger demand. Demand is more associated with economic conditions. People in emerging economies cannot afford to fly as much as those in developed countries. But as their income rises, the number of flights per person increases as well. For instance, China - the world's most populous country with over 1.3 billion inhabitants - is the only developing country among the top ten world passenger traffic contributors (OAG Aviation, 2009). Despite the fact that China's passenger share is high comparable to others (airlines registered in China carried $7 \%$ of the world's total air passengers in 2005), individual Chinese people on average travel much less when compared to the other countries using per capita basis (Figure 6). In 2011, despite GDP growth of $9.2 \%$, China's airport passenger traffic witnessed limited growth, reflecting a slowing domestic market and placing China four points lower than the world traffic/GDP growth ratio which reached 1.4 in 2011 (IMF, 2011; ACI, 2011).

In comparison and relative to population size, the importance of air travel was particularly high among the EU Member States (Table 1) for the popular holiday islands of Cyprus and Malta (8.6 and 8.4 passengers carried per inhabitant) in 2011, as well as for Iceland (7.7) and Norway (6.6). The lowest ratios were recorded for Slovakia, Romania, Poland, Slovenia, Lithuania, Hungary and Bulgaria, each reporting less than 1.0 air passengers carried per inhabitant in 2011 (Eurostat, 2012).

Table 1: Total passengers and passengers per inhabitant ratio for EU member states (2011)

\begin{tabular}{lrc}
\hline & $\begin{array}{r}\text { Total air passengers 2011 } \\
\text { (in 000) }\end{array}$ & $\begin{array}{r}\text { Passengers per inhabitant ratio } \\
\text { a }\end{array}$ \\
\hline Cyprus & 7,237 & 8.6 \\
Malta & 3,507 & 8.4 \\
Iceland & 2,463 & 7.7 \\
Norway & 32,402 & 6.6 \\
Switzerland & 41,440 & 5.3 \\
Ireland & 22,886 & 5.1 \\
Denmark & 25,805 & 4.6 \\
Spain & 165,153 & 3.6 \\
Luxembourg & 1,837 & 3.6 \\
Netherlands & 53,895 & 3.2 \\
Sweden & 29,732 & 3.2 \\
United Kingdom & 201,535 & 3.2 \\
Austria & 25,138 & 3.0
\end{tabular}




\begin{tabular}{lrr} 
Finland & 16,374 & 3.0 \\
Greece & 32,132 & 2.8 \\
Portugal & 27,578 & 2.6 \\
Latvia & 5,098 & 2.5 \\
Belgium & 25,099 & 2.3 \\
Germany & 175,316 & 2.1 \\
France & 122,887 & 1.9 \\
Italy & 116,315 & 1.9 \\
EU-27 & 776,852 & 1.6 \\
Estonia & 1,908 & 1.4 \\
Czech Republic & 12,242 & 1.2 \\
Croatia & 4,989 & 1.1 \\
Bulgaria & 6,652 & 0.9 \\
Hungary & 8,885 & 0.9 \\
Lithuania & 2,692 & 0.8 \\
Slovenia & 1,359 & 0.7 \\
Poland & 20,549 & 0.5 \\
Romania & 9,687 & 0.5 \\
Slovakia & 1,808 & 0.3 \\
\hline
\end{tabular}

\footnotetext{
${ }^{a}$ Passengers per inhabitant ratio is a result of dividing the total number of passengers carried by the number of population in a given country. This indicator shows that growing passenger demand is not always associated with population volumes, but in certain cases comes as a result of growing economic activity, as in the case of Cyprus and Malta.
}

Another perspective of the impact of population on air travel demand is the significant role played by expatriate communities in the social and economic development of their home countries through various means of interaction as remittance flows, investments and regular visits. A large diaspora or foreign workforce create an international demand for travel which is boosted by liberalisation and deregulation movements. Maintaining contacts and families at home motivates expatriates to invest into the local economy while bringing in knowledge, experience, and networks from abroad. Returning expatriates provide a source of capital and skilled labour for their home economy while outbound migrant workers rely on access to air travel to maintain the family ties in the local economy, resulting in flows of remittances for the home economy which affect the economy's local demand conditions (Khanna, 2007, Kim, 2007). An example of the impact of emigrants' home-land relations on air travel demand is the case of Lebanon. The hugh Lebanese expatriate communities-which are three times greater 
than the Lebanese residents - are said to defy the negative impact of security instability on air passenger growth through frequently visiting expats. Moreover, the emigrants' economic support to Lebanon through remittance inflows is observed to dampen the sensitivity of the relationship between passenger and GDP in times of war and peace (Itani et al., 2013).

\subsection{Technological factors:}

The technological readiness of a given economy measures the agility through which an economy adopts existing technologies to enhance the productivity of its industries. Additionally, technological readiness attracts foreign direct investments, services as a catalyst in enabling businesses to prosper and opens new markets for innovative pioneers.

Developments in Information Technology (IT), according to Hansman (2005), have had a substantial impact on the aviation industry through improving the affordability, safety, capability and efficiency of the air transport system and influencing the consumer demand for air travel. Clearly, the most significant IT factor on the airline business has been the Internet which has shifted the playing field of the traditional airline industry. Online reservations and check-in systems, electronic board and the emerging mobile applications have increased the demand for air travel. The Internet has allowed airlines to control cost and effectively manage customer relationships (Gasson, 2003). Additionally, the use of Business Intelligence Systems (BISs) within integrated airport solutions has helped airports in improving customer service, creating cost savings and greater operational efficiency. Investments in the next generation BISs will have a big implact on airport processes-from check-in, to passenger flow and facilitation, retail, aircraft turnaround and boarding (SITA, 2013).

Information Technologies will have a key role in emerging opportunities, particularly in the developing regions of the world where air transportation is a key to economic transformation. Wireless and satellite based Its have the potential to allow regions with an immature air transportation infrastructure to rapidly reach parity with mature systems. Fig. 7 depicts the growth in online travel penetration by region. Developing economies such as Eastern Europe and Latin America have witnessed over the last five years a double-digit compound average growth rate (CAGR) of online leisure and business travel of $24 \%$ and $22 \%$ respectively, 
compared to a CAGR of $9 \%$ and $4 \%$ of established economies such as Europe and the US, respectively.

\section{IDENTIFYING NATIONAL MACRO-ENVIRONMENT VARIABLES WHICH IMPACT THE OUTPUT OF A COUNTRY'S AIR TRANSPORT SECTOR}

To reach the objective of the paper and to identify the national macro-environment factors with a significant impact on air transport output, it becomes important to analyze numerically the relationship of the different factors of the macro-environment to the air transport sector's output because of the implications that this relationship would have on air transport policy orientation.

For that purpose, a sample was built including 52 countries of various stages of development from different geographical regions (Fig. 8). In the early stages of the research, the sample consisted of 150 countries. Later on during the data collection process, 98 countries were excluded due to the unavailability of consistent and credible indices respective to their macroenvironment forces. Hence the final result is a sample of 52 countries. Twenty-one different indicators were collected for each country and distributed between two categories specifically 17 input variables and four output variables (Table 2).

Input variables include the 12 pillars of national competitiveness as identified by the World Economic Forum-Global Competitiveness Report (WEF-GCR). Five input variables of macroenvironment nature are also included to test their relevance to air transport output. These five variables are: economic stage of development, travel and tourism competitiveness, population count, country surface area and the level of political and security stability. The literature reviewed in Section 2, provides examples of cases where these five additional variables are found to have an impact on the output of the air transport sector. Including these variables as inputs in this sample will demonstrate analytically whether a statistical relationship exists between the mention variables and the air transport industry output. 
As for the air transport industry output, we restricted the analysis to only four indicators due to the unavailability of reliable data on other outputs ${ }^{8}$ and limitations concerning the countries included in the sample. The four output variables used in the analysis are: total passengers per country, total contribution of air transport to national GDP, total contribution of air transport to employment and air connectivity levels.

For the sake of consistency, the data reported on all the mentioned variables is for 2009 except for the Air Connectivity Index which measures connectivity for year 2007. Table 2 provides descriptive statistics of the variables included in the sample.

Fig 7. Online leisure and business travel by world regions: penetration of total travel market $(2008-2013 *)$
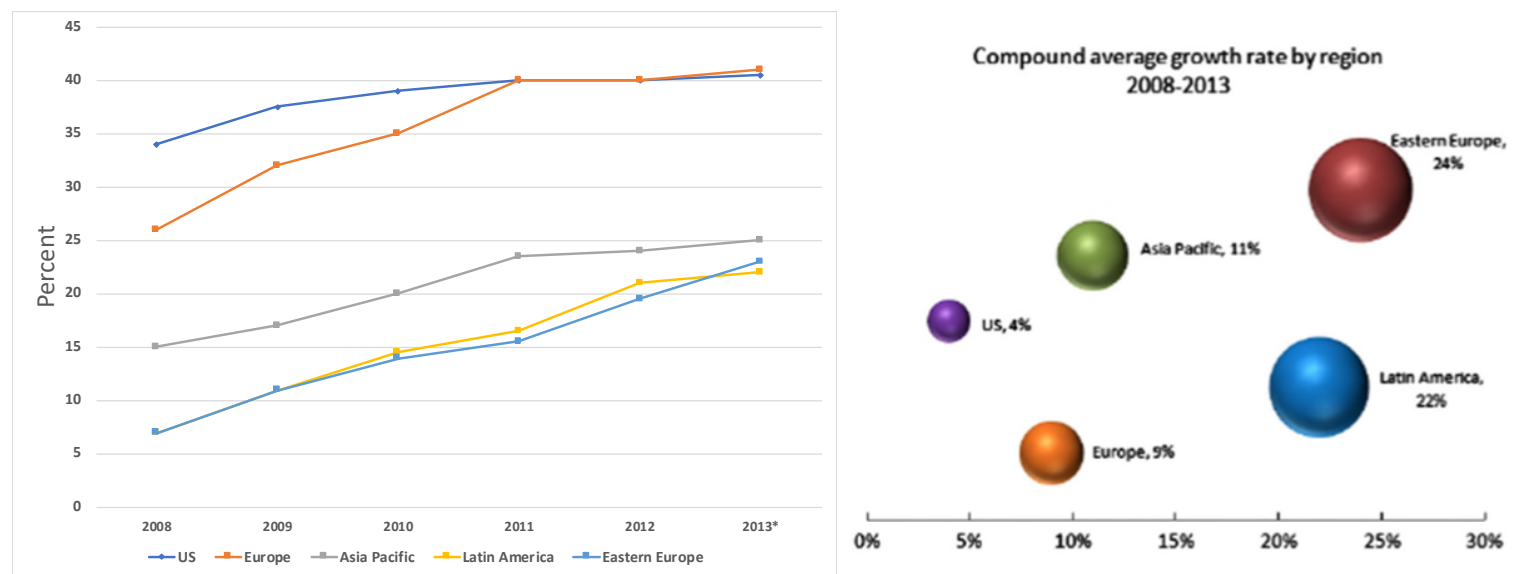

Source: (Kaci, 2012) *2013: projected

${ }^{8}$ Other outputs of air transport might include: cargo traffic, registered airlines' performance index, hub airports' performance index. 


\section{Figure 8: Countries included in the sample*}

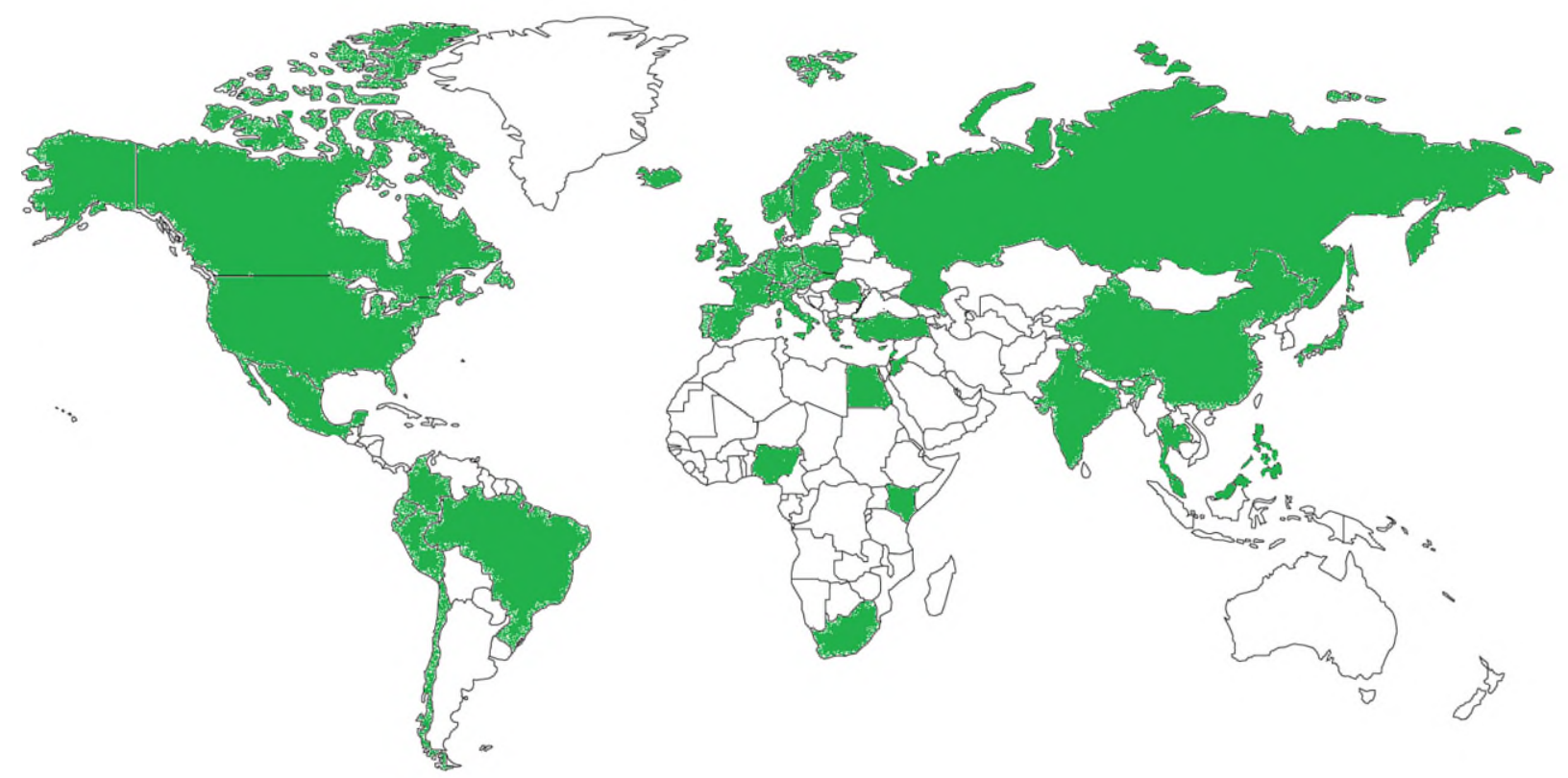

*Americas: Brazil, Canada, Chile, Colombia, Ecuador, Mexico, Peru, USA. Europe: Austria, Belgium, Cyprus, Czech republic, Denmark, Finland, France, Germany, Greece, Hungary, Iceland, Ireland, Italy, Latvia, Luxembourg, Malta, Netherlands, Norway, Poland, Portugal, Romania, Spain, Sweden, Switzerland, UK. Africa: Egypt, Kenya, Nigeria, South Africa. Asia: China, Hong Kong, India, Japan, Jordan, Lebanon, Malaysia, Philippines, Russia, Singapore, Thailand, Turkey, UAE. Oceania: Australia, New Zealand

To evaluate the significance of relationships among input and output indicators, a two- phased approach is implemented comprising different statistical techniques, namely: structural equation modelling (SEM) and boot strapping (BS). Structural equation models are statistical procedures for testing measurement, functional, predictive, and causal hypotheses. Complementing multiple regression and ANOVA methods, among others, these multivariate statistical tools are essential if one is to understand many bodies of research and to conduct basic or applied research in the behavioral, managerial, health, and social sciences (Bagozzi and Yi, 2012). The structure of interrelationships is expressed in a series of relationships amongst dependent and independent variables. Unlike regression analysis, SEM tests multi-relationships simultaneously between the suggested independent and dependent variables (Hair et al., 2006). SEM is a conformity technique often used to measure the fitness of an assumed model of relationships to the provided data. In this study it is used to identify significance of relationships among variables irrespective 
of the fitness levels, since the focus of the research is identifying the significant varibales rather than looking at the magnitude of this significance.

Due to the relaxation of the fitness requirements and the small sample size (52 countries) a BS is employed were we draw repeated samples (1000 iteration) of the original sample for the purpose of approximating the sampling distribution to ensure that it is representative enough of the population of countries as a whole and thus we can establish reliable and confident results (Mooney and Duval, 1993).

Table 2: Descriptive statistics of input and output variables included in the sample.

\begin{tabular}{|c|c|c|c|c|c|c|c|c|}
\hline Variables & Mean & Median & Std. Dev & Minimum & Maximum & Skewness & Kurtosis & Data source \\
\hline \multicolumn{9}{|l|}{ Inputs } \\
\hline Institutions & 4.58 & 4.51 & 0.97 & 2.97 & 6.15 & 0.09 & $(1.34)$ & WEF (2009a) \\
\hline Infrastructure & 4.61 & 4.59 & 1.23 & 2.29 & 6.59 & $(0.17)$ & $(1.09)$ & WEF (2009a) \\
\hline Macro-economic Environment & 4.84 & 4.75 & 0.67 & 3.43 & 5.95 & $(0.28)$ & $(0.62)$ & WEF (2009a) \\
\hline Health and primary education & 5.68 & 5.89 & 0.71 & 2.96 & 6.46 & $(1.95)$ & 4.49 & WEF (2009a) \\
\hline Higher education and training & 4.70 & 4.65 & 0.71 & 3.03 & 5.97 & $(0.17)$ & $(0.67)$ & WEF (2009a) \\
\hline Goods market efficiency & 4.65 & 4.69 & 0.53 & 3.32 & 5.77 & $(0.18)$ & $(0.52)$ & WEF (2009a) \\
\hline Labour market efficiency & 4.62 & 4.67 & 0.62 & 3.26 & 5.95 & 0.18 & $(0.14)$ & WEF (2009a) \\
\hline Financial market development & 4.68 & 4.67 & 0.58 & 3.27 & 5.91 & $(0.15)$ & $(0.28)$ & WEF (2009a) \\
\hline Technological readiness & 4.58 & 4.62 & 1.00 & 2.90 & 6.15 & $(0.08)$ & $(1.40)$ & WEF (2009a) \\
\hline Market size & 4.68 & 4.61 & 0.97 & 2.41 & 6.93 & $(0.13)$ & 0.18 & WEF (2009a) \\
\hline Business sophistication & 4.70 & 4.75 & 0.63 & 3.42 & 5.89 & 0.09 & $(0.82)$ & WEF (2009a) \\
\hline Innovation & 3.92 & 3.80 & 0.86 & 2.34 & 5.77 & 0.43 & $(0.71)$ & WEF (2009a) \\
\hline Economic stage of development & 4.10 & 5.00 & 1.24 & 1.00 & 5.00 & $(1.28)$ & 0.73 & WEF (2009a) \\
\hline Travel and tourism competitiveness & 4.65 & 4.82 & 0.58 & 3.02 & 5.68 & $(0.51)$ & $(0.35)$ & WEF (2009b) \\
\hline population count & $90,049,124$ & $19,277,850$ & $242,841,973$ & 317,398 & $1,338,299,511$ & 4.56 & 20.89 & United Nations (2012) \\
\hline Country size & $1,575,131$ & 307,001 & $3,441,009$ & 316.00 & $17,098,242$ & 2.92 & 8.66 & United Nations (2013) \\
\hline Political and security stability & 1.77 & 1.65 & 0.45 & 1.20 & 2.75 & 0.65 & $(0.63)$ & IEP (2009) \\
\hline \multicolumn{9}{|l|}{ Outputs } \\
\hline Total passengers & $65,529,775$ & $26,971,319$ & $139,124,778$ & $1,365,343$ & $964,402,413$ & 5.59 & 35.45 & ICAODATA (2009) \\
\hline Aviation contribution to GDP & 4.62 & 3.10 & 4.36 & 0.60 & 18.00 & 1.70 & 2.23 & Oxford Economics (2010) \\
\hline Aviation contribution to employment & 4.64 & 3.15 & 4.37 & 0.50 & 19.70 & 1.85 & 3.17 & Oxford Economics (2010) \\
\hline Air connectivity index & 6.48 & 5.80 & 3.94 & 1.08 & 22.78 & 1.57 & 4.35 & The World Bank (2011) \\
\hline
\end{tabular}

Bootstrapping estimates SEM parameters for the new sample and then determines the values for the parameter estimates. Specifically, BS is used to estimate the significance from repeated sampling (1000 iterations) of the original sample (52 countries) to ensure that it is representative sample of the population of countries as a whole.

A graphical representation of SEM path analysis ${ }^{9}$ showing the direction and strength of the relationships between the set of 17 input (independent) variables and the four output (dependent) variables is provided in Figure 9. The node F1 stands for the total unobserved output ${ }^{10}$ of a given country's air transport sector which is measured by only the four output variables.

\footnotetext{
${ }^{9}$ AMOS version 16 is used to obtain SEM results.

${ }^{10}$ The unobserved output is also referred to as latent output. This comprises the air transport output factors which are measured in this model because of the unavailability of data corresponding to countries included in the
} 
Figure 9: SEM relationships between macro-environment input variables and air transport sector output variables

sample. These factors are cargo traffic, level of performance of registered carrier sad the level of efficiency of hub airports. 


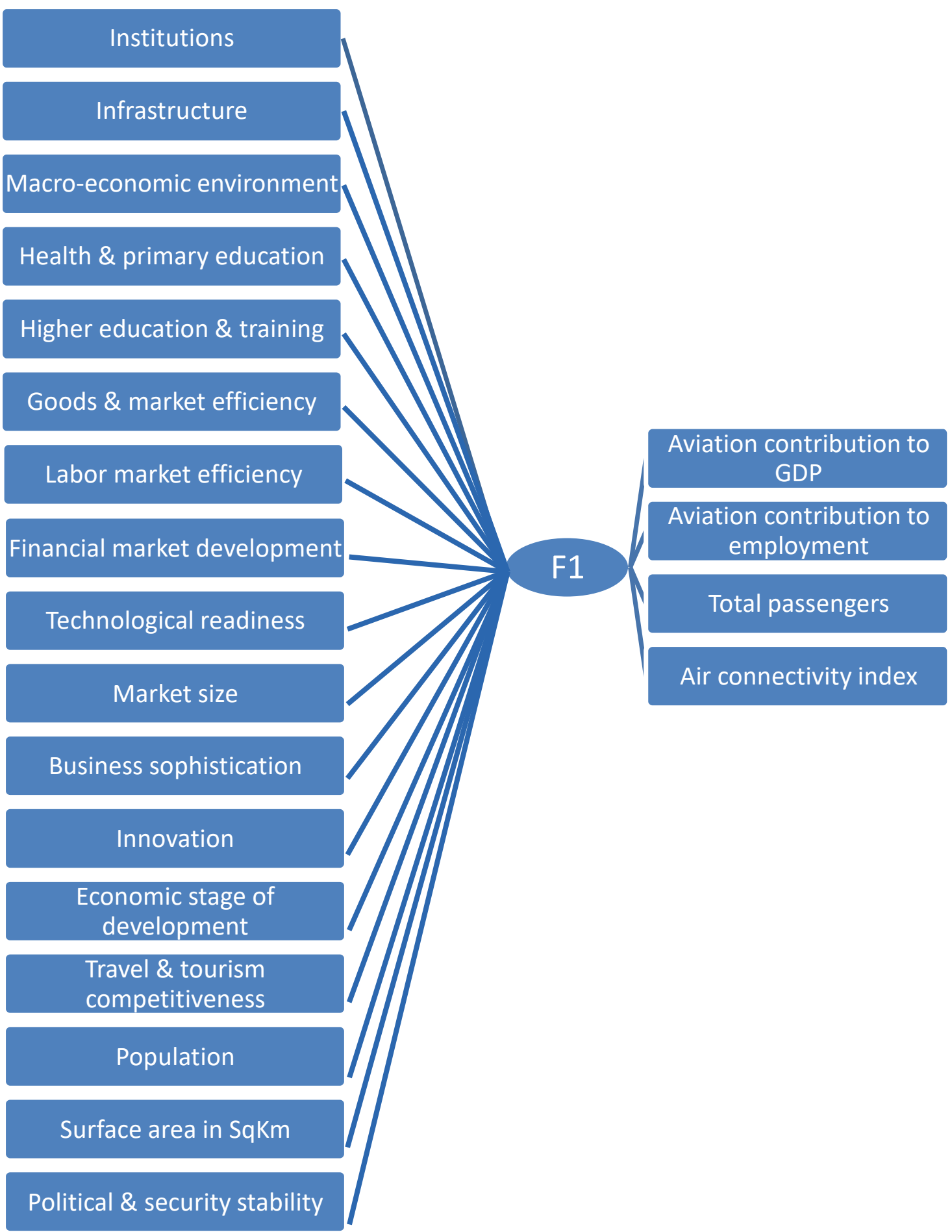

The values next to each input in Fig.9 represent the average significance level (average $P$-value) of the four output variables in relation to each input variable. More detailed reporting is show in 
Table 3 where the four significance value are available next to each input in addition to the average $P$-value in the final column.

Results are reported at $95 \%$ confidence level. Variables with a $P$-value $<0.05$ are selected as factors with relatively higher significance in relation to air transport industry output when compared to other variables. ${ }^{11}$ The results of the combined approach of SEM plus the BS technique showed that out of 17 input (independent) variables, 12 are found significant in relation to air transport sector's output (dependent) variables which are included in this analysis. Political and security stability is said to be the factor with the highest significance value at 0.004 followed by Goods market efficiency at 0.006; whereas, the least significant factor is the Economic stage of development at 0.567. Additionally, it is obvious from the results that the 12 significant inputs are related to the four outputs differently; however, five inputs (political and security stability, goods market efficiency, innovation, market size, and institutions) share the same impact of $<0.001$ on two common variables (aviation contribution to GDP and aviation contribution to employment). Moreover, the country surface area, infrastructure, and travel and tourism competitiveness, are said to be the most significant inputs in relation to air connectivity levels. This is evident in the case of the USA which ranks first in the air connectivity index on the one hand and ranks among the the top ten countries in terms of infrastructure (rank 7) and travel and tourism competitiveness (rank 8) on the other.

The five variables with a lesser significance are: business sophistication, financial market development, economic stage of development, technological readiness and population count.

\section{Table 3: significance levels (P-values) of input variables to each output variables}

\footnotetext{
${ }^{11}$ Only the significance levels are provided and not the coefficients. The objective of the paper is to identify variables with significant relationships to air transport output rather than investigating the magnitude of this significance.
} 


\begin{tabular}{|c|c|c|c|c|c|}
\hline & Total passengers & Aviation contribution to GDP & Aviation contribution to employment & Air connectivity & Average \\
\hline Political and security stability & 0.004 & $<0.001$ & $<0.001$ & 0.003 & 0.004 \\
\hline Goods market efficiency & 0.009 & $<0.001$ & $<0.001$ & 0.002 & 0.006 \\
\hline Innovation & 0.003 & $<0.001$ & $<0.001$ & 0.015 & 0.009 \\
\hline Health and primary education & 0.007 & 0.022 & 0.001 & 0.018 & 0.012 \\
\hline Surface area & 0.017 & 0.010 & 0.012 & $<0.001$ & 0.013 \\
\hline Higher education and training & 0.029 & 0.009 & 0.017 & 0.005 & 0.015 \\
\hline Market size & 0.008 & $<0.001$ & $<0.001$ & 0.022 & 0.015 \\
\hline Travel and tourism competitiveness & 0.026 & 0.004 & $<0.001$ & $<0.001$ & 0.015 \\
\hline Infrastructure & 0.034 & $<0.001$ & 0.007 & $<0.001$ & 0.021 \\
\hline Macro-economic environment & $<0.001$ & 0.007 & 0.029 & 0.038 & 0.025 \\
\hline Institutions & 0.036 & $<0.001$ & $<0.001$ & 0.025 & 0.031 \\
\hline Labour market efficiency & 0.012 & 0.049 & $<0.001$ & 0.046 & 0.036 \\
\hline Technological readiness & $<0.001$ & 0.072 & 0.095 & 0.259 & 0.142 \\
\hline Business sophistication & 0.007 & 0.379 & 0.466 & 0.062 & 0.229 \\
\hline Population count & 0.001 & 0.538 & 0.591 & 0.428 & 0.390 \\
\hline Financial market development & 0.563 & 0.296 & 0.818 & 0.395 & 0.518 \\
\hline Economic stage of development & 0.032 & 0.973 & 0.747 & 0.516 & 0.567 \\
\hline
\end{tabular}

It is worth mentioning that four out of the five variables (business sophistication, economic stage of development, technological readiness and population count) displayed significance with one common output, which is passenger numbers, as show in Table 3.

Of the five additional inputs which are not included in the WEF pillars of global competitiveness and are added to the model (travel and tourism competitiveness, population count, country surface area, economic stage of development and the level of political and security stability), three are found to be of high significance to air transport output. This confirms the importance of political and security stability, travel and tourism performance and the country size in creating a more enabling environment for the air transport to produce an efficient output.

The reported results applied within the context of Porter's framework for national advantage ${ }^{12}$ led to the development of a diagram which defines the operating environment drivers determining the competitiveness of the air transport system on a national level (Fig. 10). Each point on the diamond - and the diamond as a whole - is a dynamic system in which all elements interact and reinforce each other, thus creating a competitive air transport industry deriving its strength for the nation's overall competitiveness. This proves that an enabling environment idenfies the capacity of a country to benefit from the use of its macro-drivers to support tha ir

\footnotetext{
12 To explain why a nation succeeds in particular industries but not in others Porter developed an analytical framework which he calls "The diamond of national advantage". This framework incorporates four attributes of the home environment - namely; (1) factor conditions (2) demand conditions (3) related and supporting industries (4) strategy, structure and rivalry.
} 
transport system output. Additionally, the maturity of the macro-environment and the leveraging of the identified factors remain pre-conditions for obtaining positive results.

This encourages governments to create a suitable context which will back the air transport industry's growth potential. The suggested framework serves as an assessment tool for policy makers to identify strengths on which to build and weaknesses that need to be addressed within national policies. Moreover, it allows governments to benchmark the performance of its national drivers of competitiveness against those of other well-performing countries to determine the degree of the environmental conditions' readiness to assist the air transport sector to compete both on national and international levels.

\section{Figure 10: Factors determining the competitiveness of air transport}

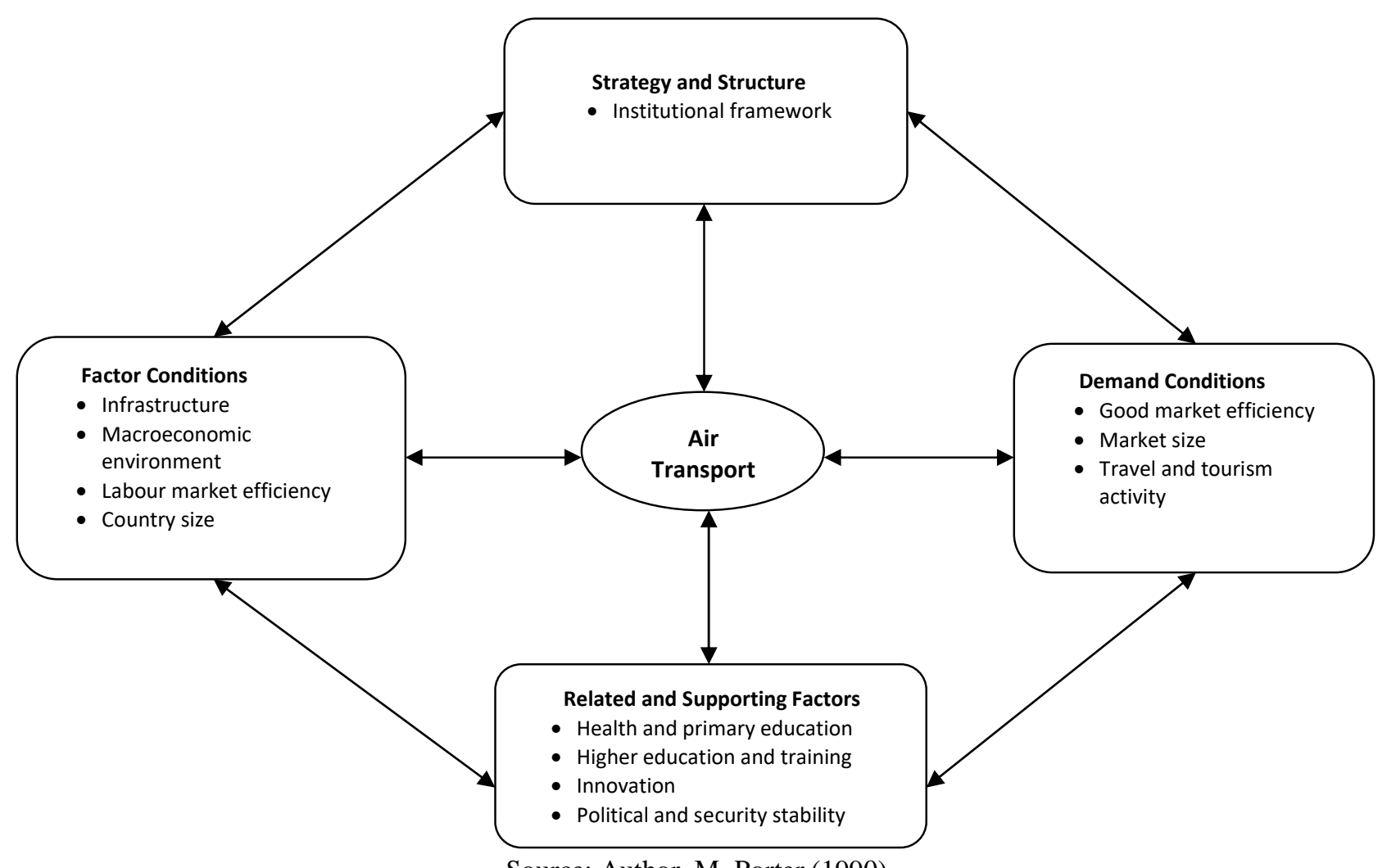

Source: Author, M. Porter (1990)

\section{CONCLUSION}


The concept of economic competitiveness affirms that the national environment in which industries operate can enhance or hinder their ability to compete nationally and internationally. This macro-environment is essential to analyse while industry planners are drawing strategies for the future. The hypothesis of the influence of national macro-environment factors on air transport sector performance is tested through putting a set of 21 variables are put under examination. Seventeen input macro-environment (independent) variables are statistically tested against four output (dependent) variables representing the air transport sector output. Due to the scarcity of consistent and credible data on air transport sector output, the sample size was reduced from 150 to 52 countries.

The results of the SEM, show that there exists a dependency between the stated macroenvironment forces and air transport output. However, at a confidence level of 95\%, 12 input variables showed high significance $(\mathrm{P}$-value $<0.05)$. The identified significant drivers create an enabling environment that determines the capacity of an economy and society to benefit from air transport system's productivity. The success of a country in leveraging the air transport sector and in achieving the desired economic and social benefits will depend on its overall environment, including political and security stability, good market efficiency, market size and its conditions, appropriate infrastructure, labour market efficiency, maturity of the health and education systems and its competitiveness in the travel and tourism sector.

The identified operating environment conditions act as a framework for providing clear policy orientations and for facilitating the identification of areas where policy intervention - through encouraging investments, including public-private partnerships; industry deregulation steps; or other liberal approaches to market access - could boost the air transport sector performance. This is important because the development and sustainability of the air transport system depends on the capacity of a country to provide an institutional framework with reliable and efficient rules and regulations; favourable business conditions to attract investments and trigger the birth and growth of new enterprises; an innovation-prone environment, capable of developing and absorbing new knowledge; a proper infrastructure capable of matching the increasing demand for air travel; and an appropriate air transport policy.

\section{REFERENCES}


- ACI (20010, Wold Airport Traffic report, Airports Council International, Montreal, Canada.

- Alderighi, M., Centro, A., 2004. European airlines conduct after September 11. J. Air Transport Manage. 10 (2), 97-107.

- Ansoff, H. I., 1965. Corporate Strategy: An Analytical Approach to Business Policy for Growth and Expansion, McGraw-Hill, New York.

- ATAG, 2012. Aviation Benefits Beyond Borders. Air Transport Action Group, Geneva, Switzerland.

- Bagozzi, R. and Yi, Y. 2012. Specification, evaluation, and interpretation of structural equation models, J. Acad. Market. Sci. 40 (1). 8-34.

- Barry, B., 1997. Strategic Planning Workbook for Non-profit Organizations. Wilder Foundation, St. Paul, MN.

- Berger. T., Bristow, G., 2009. Competitiveness and the benchmarking of nations-a critical reflection. Int. Adv. Econ. Res. 15 (4), 378-392.

- Boeing, 2010. Current Market Outlook: 2011 to 2030. Boeing Company, USA.

- Burns, B., 2004. Managing Change: A Strategic Approach to Organisational Dynamics/Bernard Burnes, fourth ed Prentice Hall, Harlow: FT (2004)

- Button, K., 2009. The impact of US-EU “'Open Skies”' agreement on airline market structures and airline networks. J. Air Trnaport Manage. 15 92) 59-71.

- Chochrane, P., 2009. An Embargo that Shouldn't Fly, $122^{\text {nd }}$ ed. The Executive Magazine, Lebanon.

- Cooper, A. Smith, P., 2005. The Economic Catalytic Effects of Air Transport in Europe, EUROCONTROL, United Kingdom (004)

- De Soto, H., 2000. The Mystery of Capital: Why Capitalism Triumphs in the West and Fails Everywhere Else? Basic Books, USA, New York

- Dobruszkes, F., Van Hamme, G., 2011. The impact of the current economic crisis on the geography of air traffic volumes: an empirical analysis. J. Transport Geogr. 19 (6), 13871398.

- Endres, G., 2008. In from the Cold. Airline Bus. 24 (6), 56-58

- EuroMonitor, 2012. Transportation in Egypt. EuroMonitor International.

- EUROSTAT (2012), Passenger Transport Statistics, available at: epp.eurostat.ec.europa.eu.

- Fifield, P. Gilligan, C. 2000. Strategic Marketing Management 2000-2001: Planning and Control/ [by] Paul Fifield and Colin Gilligan, Butterworth-Heinemann, Oxford. P. 2000

- Flight Global, 2013. Air Transport Intelligence: airlines and airports profile. Reed. Bus. Inf.

- Franke, M., John, F., 2011. What comes next after recession? - Airline industry scenarios and potential end games. J. Air Transport Manage. 17 (1), 19-26.

- Gasson, S., 2003. The Impact of E-commerce Technology on the Air Travel Industry. Drextel University, USA

- Hair, J.F., Black, W., Babin B., Anderson, R., 2006. Multivariate Data Analysis, seventh edition. Pearson Education, New Jersey, USA

- Hanke, S.H., Walerers, S.J.K., 1997. Economic freedom, prosperity, and equality: a survey, CATO J. 17 (2), 117. 
- Hansman, J., 2005. The Impact of Information Technology on Air Transportation. American Institute of Aeronautics and Astronautics (AIAA), USA

- Hätty, H., Hollmeier, S., 2003. Airline strategy in the 2001/2002 crisis - the Lufthansa example. Journal of Air Transport Manage. 9 (1), 51-55.

- Henry, I., 2010. The influence of external environmental factors on tourism market strategies in Africa. Advances in Hospitality and Leisure 6 (6) 215-222.

- Hourani, G. (2007), Lebanese Diaspora and Homeland Relations, , The Forced Migration and Refugee Studies Program, Egypt.

- IADB, 2004. Infrastructure, Competition Regimes and Air Transport Costs: Cross Country Evidence, WPS510. Inter American Development Bank, USA.

- ICAO (Sept 2007), Outlook for Air Transport to the Year 2025

- ICAODATA (2009), Total Scheduled Passenger Traffic by Country, available at: (icaodata.com)

- ICAODATA, 2010. Regional Distrbution of Scheduled Traffic. International Civil Aviation Organisation, Canada

- ICAODATA (2012), Total Passenger Traffic for Dubai, available at: (icaodata.com)

- IEP, 2009. Global Peace Index (GPI). Institute for Economics and Peace, Australia

- IMF, 2011. World Economic Outlook-Data Mapper. International Monetary Fund

- IMF, 2012. World Economic Outlook-Data Mapper. International Monetary Fund

- InterVISTAS-ga2, 2006. The Economic Impact of Air Service Liberalization, InterVISTAS Consulting, Inc., USA

- Ishutkina, M., Hansman, J. (2009), Analysis of the Interaction between Air Transportation and Economic Activity: A Worldwide Perspective. Doctor of Philosophy Thesis, Massachusetts Institute of Technology, United States of America.

- Itani, N., O’Connell, J.F., Mason, K., 2013. The impact of emigrants' homeland relations on air travel demand in a security volatile market: a case study on Lebanon. J. Transport Geogr. 30, 170-179.

- Kaci, F., 2012. Online Travel Overview: Innovations Shake Trave. PhoCusWright

- Khanna, T., 2007. CHINA + INDIA the Power of Two, Harvard Bus Rev. 85 (12), 60-69.

- Kim, N. (2007), The Impact of Remittances on Labour Supply: The Case of Jamaica, WPS4120. World Bank.

- Koteen, J., 1989. Strategic Management in Public and Non-profit Organizations: Thinking and Acting Strategically on Public Concerns. Praeger Publishers, New York, USA.

- Laessing, U., Abdelaziz, K. (2011), Sanctions are Hell for Sudan Airways which Struggles to Survive., avialble at: <http://www.alarabiya.net/articles/2011/12/16/182956.html> .

- Lall, S., 2001. Competitiveness indices and developing countries: an economic evaluation of the global competitivess report. World Dev. 29 (9) 1501-1525.

- Lyford, C., Ricks, D., Peterson, C., Sterns, J., 2002. A framework for effective industry strategic planning. Journal of Agribusiness 20 (2), 131-146.

- McFetridge, D., 1995. No. 5: Competitiveness: Concepts and Measures. Industry Canada, Canada.

- Mintzberg, H., 2000. The Rise and Fall of Strategic Planning. FT Prentice Hall, London.

- Mintzberg, H., Ahlstrand, B., Lampel, J., 1998. Strategy Safari: A Guided Tour Through the Wilds of Strategic management. Prentice Hall Europe, Hemel Hempstead. 
- Mooney, C., Duval, R., 1993. Bootstrapping: A Non-Parametric Approximation to Statistical Inference. Sage Publications, London, UK.

- Nutt, P.C., Backoff, R.W. 1995. Strategy for public and third sector organizations. J. Public Admin. Res. Theory 5 (2), 189.

- OAG Aviation, 2009. Air Trips per Capita: World UBM Aviation.

- Oral, M., Chabchoub, H.1996. On the methodology of the world competitiveness report. Eur. J. Oper. Res. 90 (3), 514-535.

- Oxford Economics, 2010. Economic Benefits from Air Transport: Country Reports. Oxford Economics, United Kingdom

- Oxford Economics, 2011. Economic Benefits from Air Transport in Egypt. Oxford Economics, United Kingdom

- Pirie, G., 1992. Southern Africa air transport apartheid. J. Modern Afr. Stud. 30 (2), 341348.

- Poore, J. W., 1993. Forecasting the demand for air transportation services. J. Transp. Eng. 19 (5), 22-34

- Porter, M.E., 1998. Competitive Advantage of Nations. With a New Introduction. New ed Mcmillan

- Porter, M. E., 2004. Competitive Advantage: Creating and Sustaining Superior Performance. The Free Press. First Free Press export ed. New York

- Ricks, D., Woods, T., 1996. "Strategic planning for improved competitiveness by regional commodity industries. J. Food Distrib. Res. 27(1)

- Rodrigue, J. Comtois, C., Slack, B., 2013. The Geography of Transport Systems, third ed. Routledge, Abindon, Oxon,

- Rouvinen, P., 2001. Finland on the top of the competitiveness game. Finnish Econ. Society 4, 53-60.

- Saisana, M., Tarantola, S., 2002. Current Methodologies and Practices for Composite Indicators Development. 20408. European Commission Joint Research Centre, Ispra, Italy

- Schafer, A., Victor, D.G., 2000. The future mobility of the world population. Transp. Res. Part A 34, 171-2005.

- $\quad$ SITA (2013), Air Transport IT Review, Issue 2, SITA.

- The Economist (13 August 2011), Is the Revolution Good for Business in Egypt? Available at: 〈http://www.economist.com/node/21525924>

- The World Bank, 2011. The Air Connectivity Index, WPS5722. World Bank Publications.

- Thompson, A.A., Gamble, J.E., Strickland III, A.J., 2004. Stategy: Winning in the Marketplace: Core Concepts, Analytical Tools, Cases. McGraw-Hill, Boston, Mass,

- United Nations (2012), World Population Prospects, United Nations

- United Nations (2013), World Statistics Pocket Book, United Nations

- UNWTO (2013), Tourism Highlights Report, United Nations World Tourism Organization, Spain.

- Vandyk, A., (September 1, 1991), To Evade an Embargo: Libyan Arab Airlines Wants to Update its Fleet to Meet a Rise of Tourism but a U.S. High-tech Ban is in the Way, Air Transport World. 
- Vartia, P., Nikinmaa, T., 2004. What do competitiveness comparisons tell us? Finnish Econ. Society 4, 74-79

- WEF, 2009a. Global Competitiveness Report. World Economic Forum, Geneva.

- WEF, 2009b. Travel and Tourism Competitiveness Report. World Economic Forum, Switzerland.

- WEF, 2012. Global Competitiveness Report. World Economic Forum, Geneva.

- WEF 2013. Travel and Tourism Competitiveness Report. World Economic Forum,.

- Young, R., 2001. Perspectives on Public Budgeting: Budgets, Reforms, PerformanceBased Systems, Politics and Selected State Experiences. University of South Carolina, USA 


\title{
Cranfield University
}

2014-04-03

\section{A macro-environment approach to civil aviation strategic planning}

\author{
Itani, Nadine
}

Elsevier

Itani N, O'Connell JF, Mason K. (2014) A macro-environment approach to civil aviation strategic planning. Transport Policy, Volume 33, May 2014, pp. 125-135

https://doi.org/10.1016/j.tranpol.2014.02.024

Downloaded from Cranfield Library Services E-Repository 